\title{
Cullure and the Judiciary : The Meaning of the Culture Concept as a Source of Aboriginal Rights in Canada
}

Ronald Niezen

\section{An Unstable Concept as a Source of Rights?}

Many ideas that carry dark histories and hidden agendas appear on first sight simple, straightforward and readily acceptable. When, in particular, sociological or anthropological concepts make a transition into law they are susceptible to being imbued with orthodoxy, receiving as they do the imprimatur of judicial legitimation. When the judiciary makes use of sociological concepts, critical attention requires a leap across a divide that can perhaps best be described as a trans-disciplinary abyss, one that inhibits the back and forth traffic required of analysis, tending to leave pivotal, historically laden concepts unexamined.

A 1996 decision by the Supreme Court of Canada affirms, in just such a seemingly innocuous way, that aboriginal peoples have constitutionally entrenched cultural rights: "Aboriginal rights," the Court states in $R$. v. Van der Peet, "arise from the prior occupation of the land, but they also arise from the prior social organization and distinctive cultures of aboriginal peoples on that land." This might appear to be something progressive, something to be unconditionally welcomed. With this statement and the orientation to aboriginal rights that goes with it, culture has found an open place in the legal realm, no longer having to approach the courts under disguise or enter through side avenues. A concept popularly associated with anthropologists has entered the realm of law and developed into a source of distinct rights.

A central irony associated with judicial use of the culture concept is the fact that it corresponds with the emergence of a widely accepted approach to culture in anthropology that dismisses its value as a category of "thing," as a noun that can be identified, described, compared with others, displayed in museums, presented at conferences, and by extension, decided upon in courts. For James Clifford, one of the early proponents of the unstable approach to culture, the inexplicit nature of the concept of culture was revealed by the ambiguities and intellectual dissonances of a 1976 trial in which the pivotal issue was to determine whether or not the group calling itself the Mashpee Tribe should in fact be accorded recognition as a tribe by the U.S. government (as a preliminary step in settling land claims). "The culture concept," Clifford concludes, "accommodates internal diversity and an 'organic' division of roles but not sharp contradictions, mutations, or

R. v. Van der Peet, [1996] 2 S.C.R. 507 at para. 3.

Canadian Journal of Law and Society / Revue Canadienne Droit et Société, 2003, Volume 18, no. 2, pp. 1-26 


\section{Ronald Niezen}

emergences (...) It sees tribal 'traditionalists' and 'moderns' as representing aspects of a linear development, one looking back, the other forward. It cannot see them as contending or alternating futures." ${ }^{2}$ The outcome of the Mashpee trial-the Court's denial of the distinctive status of a community that seemed nevertheless to embody many of the complexities and ambiguities of distinct culture-serves to highlight the difficulty of translating sociological abstractions into the kind of formal conceptual clarity privileged by the judiciary. Another seminal work on self-conscious cultural innovation and political mobilization edited by Eric Hobsbawm and Terrence Ranger, The Invention of Tradition, ${ }^{3}$ discusses the use of symbols and ceremonies by colonial powers to create histories and traditions where none had previously existed. Culture, in this set of examples, is a near miraculous ideological raw material used to shore up regimes on the brink of illegitimacy. Such a mobile approach to the idea of culture has been further developed by Arjun Appadurai, who argues that Culture should be looked at as adjectival rather than as a noun, as a process rather than a thing, as an integral part of identity formation not a paradoxical object of fixed history. For Appadurai, culture, or rather the cultural, describes a peoples' connection to "those differences that either express, or set the groundwork for, the mobilization of group identities."4 Thus, the ambiguities of culture as inseparable from identity formation are now commonly recognized as an integral part of the anthropological and historical points of view. Cultures are now widely considered collective inventions, with varying degrees of self-conscious manipulation built into the attachments people have to "timeless" ways of life. They are "isms," the products of national awakening, created and defended by those who are erecting new political boundaries.

If there is an emerging consensus that culture is inherently unstable and subjective, how can the Court make decisions with any confidence that affirm or deny cultural rights? It is true that there is no stability in any of the important concepts regularly wielded by courts or legislative bodies. The United Nations, for example, functions perfectly well without a formal definition of the State and courts everywhere do their work without defining "law." But concepts like "culture," "tradition," or "way of life" somehow seem especially insecure. Today they are associated with identity, with the all important question "who are we?" And this, it should be immediately evident, is difficult to pin down by those, no matter how anthropologically or legally competent, who do not personally share the question's selfdefining answer(s). In order to reach this summit of instability, the concept

James Clifford, The Predicament of Culture (Cambridge Mass: Harvard University Press, 1988) at 338.

3 Eric Hobsbawm \& Terrence Ranger, eds., The Invention of Tradition (New York: Columbia University Press, 1983).

4 Arjun Appadurai, Modernity at Large: Cultural Dimensions of Globalization (Minneapolis: University of Minnesota Press, 1996) at 13. 
has gone through several mutations or "paradigm shifts" within the short period of time-short even by the measure of intellectual history-since its emergence in the nineteenth century, making it even more evident that it is not something that can be relied upon, least of all as a source of legally entrenched rights.

The Canadian courts' recent forays into aboriginal cultural rights are a change of direction, and the existing body of case law, largely tied to legislation, treaties and other agreements, does not provide sure guidance through the complexities and abstractions of cultural attachments. The distinct qualities of aboriginal cultures occupy an oral realm, difficult to grasp in terms of legal regularity and certainty.

Establishing the possibility that the Court has elaborated-and based judgments on-a largely tacit conceptualization of culture raises more than just immediate critical concerns; it raises a more basic, enduring question concerning the sources of this judicial sociology. How do the courts seek knowledge about aboriginal practices and customs that may be unfamiliar to those required to make rulings? More generally, how does the judiciary arrive at the anthropological/sociological ideas on which some of their decisions are based? If judges are, in sociological matters, very much like specially informed laypersons, how do they acquire their information? To the extent that decisions rely not only on "facts" but also on sociological ideas, where do these ideas come from and how are they developed? The central issue I have raised here can realistically only be fully addressed through a broad application of cultural theory and legal analysis, scholarly pursuits that tend naturally to separate and that, when brought together, are not easily condensed. By way of initiating such an effort in this paper, however, I will examine these questions with a focus on the concept of aboriginal culture.

\section{Culture According to the Judiciary}

There are three basic starting points taken by the Court in recent decisions concerning aboriginal rights, each with its own degree of emphasis on aboriginal cultures. A summary of these approaches reveals a recent willingness by the courts to recognize and affirm the rights of aboriginal peoples to their own culture, albeit in ways that to some degree limit the scope of accepted cultural practice.

One approach, focusing on treaty rights (taken, for example, in $R$. v. Marshall), attempts to restrict the scope of contemporary rights to the contractual content of treaties between aboriginal peoples and the Crown. Like cultural rights, the interpretation of treaties has undergone modification with the view, confirmed in $R$. v. Marshall, that treaty arrangements "must be interpreted in a manner which gives meaning and substance to the oral promises made by the Crown during the treaty negotiations" and that the Court should be open to "the extrinsic evidence of the historical and cultural 


\section{Ronald Niezen}

context of a treaty"5 in interpreting its meaning and hence the rights it confers. A common feature of recent court decisions, therefore, is the use of ideas or perceptions of traditional, pre-contact aboriginal culture in order to determine the scope of contemporary aboriginal rights.

Cases involving claims of aboriginal land rights (as elaborated, for example, in Delgamuukw v. British Columbia) call for more careful consideration of aboriginal tradition. Aboriginal title encompasses the right to exclusive use and occupation of land and is "not restricted to the right to engage in activities which are aspects of aboriginal practices, customs and traditions integral to the claimant group's distinctive aboriginal culture." But determining the extent of those lands has involved delving in significant detail into such things as patterns of subsistence, patterns of mobility and occupancy of lands, social organization and self-government. Such information is not likely to be reliably recorded in written historical records, and the process of determining aboriginal peoples' uses of and attachments to their traditional lands has involved a wide range of expert testimony from ethno-historians, anthropologists, archaeologists, geographers, linguists and aboriginal elders. The focus of such testimony is on the patterns of use and occupancy of land that give rise to aboriginal title. Delgamuukw v. British Columbia separates culture from aboriginal land rights by setting the principle that there is no requirement to demonstrate continued attachment to distinct practices in order to establish aboriginal rights to land. Although cultural patterns are significant in establishing aboriginal land claims, and although Delgamuukw sets out new standards for the recognition of aboriginal testimony, the courts do not approach land claims as a means of protecting distinct aboriginal cultures.?

The cultural rights approach (taken, for example, in $R$. v. Van der Peet), by contrast, is almost exclusively based on consideration of the concept of culture, attempting to discern the scope of contemporary rights by elucidating the significant, distinctive practices of an aboriginal individual's (or community's) pre-contact ancestors. "Aboriginal rights arise from the prior occupation of the land," the Court states in $R$. v. Van der Peet, "but they also arise from the prior social organization and distinctive cultures of aboriginal peoples on that land." ${ }^{\prime 8}$ The Court's basis for understanding precontact cultural practices underwent change in the Delgamukw decision, which allowed the "recollection of aboriginal life" from personal and family history to be a source of testimony. In $R$. v. Van der Peet this reference point

R. v. Marshall (No. 2), [1999] 3 S.C.R. 533 at para. 2.

Delgamuukw v. British Columbia, [1997] 3 S.C.R. 1010 at para. 3.

Dara Culhane provides a detailed examination of the Delgamuukw case, with an emphasis on judicial process as a mechanism for the extinguishment of distinct aboriginal rights and title. See Dara Culhane, The Pleasure of the Crown: Anthropology, Law and First Nations (Burnaby, British Columbia: Talon Books, 1998).

8 Van der Peet, supra note 1 at para. 3. 
is taken further, and "aboriginal life" becomes in itself a source of distinct rights.

The influence of anthropological ideas in judicial decision making goes back as far as the comparative study of human societies in the nineteenth century and its continued influence in the twentieth. For nineteenth century socio-evolutionists, the culture concept answered a need to fit all human societies into a unilineal hierarchy of complexity, sophistication, development and virtue, above all in comparison with (or more precisely, in contrast to) the pinnacle of human achievement, "civilization." Culture was an extremely broad, "catch-all" concept-covering the entire range of human institutions, values, customs, and practices-that allowed theorists, sometimes called "comparative ethnologists," to situate human societies on a scale of development, with positive value placed on those aspects of culture that accorded well with European society: technological sophistication, monogamous marriage, legal codes that protect individuals (including private property), and monotheistic religion.

Not surprisingly, evolutionist approaches to human differences are evident in the earliest rulings in English law that express a legal theory of culture. ${ }^{9}$ In re Southern Rhodesia, a 1919 decision by the Committee of the Privy Council to determine property rights after the conquest of an African kingdom by the British South Africa Company, is a clear example of an evolutionist approach to culture in a judicial decision. The finding of the Privy Council in this case pertained specifically to the ability of an Indigenous African kingdom to assert rights and interests after conquest. But it determined these interests through general cultural principles:

The estimation of the rights of aboriginal tribes is always inherently difficult. Some tribes are so low in the scale of social organization that their usages and conceptions of rights and duties are not to be reconciled with the institutions or legal ideas of civilized society. Such a gulf cannot be bridged. It would be idle to impute to such people some shadow of the rights known to our law and then to transmute it into the substance of transferable rights of property as we know them (...) On the other hand, there are indigenous peoples whose legal conceptions, though differently developed, are hardly less precise than our own. When once they have been studied and understood they are no less enforceable than rights arising under English law. Between the two there is a wide tract of much ethnological interest, but the position of the native of Southern Rhodesia within it is very uncertain; clearly they approximate rather to the lower than to the higher limit. ${ }^{10}$

9 The following summary of the antecedents of the Canadian Supreme Court's approach to culture owes a great deal to Michael Asch's "The Judicial Conceptualization of Culture after Delgamuukw and Van der Peet" (2000) 5:2 Rev. Const. Stud. 119.

10 In re: Southern Rhodesia, (1919) AC 210 (PC) note 4 at 233-34, cited in Asch, ibid. at 121. 


\section{Ronald Niezen}

Aboriginal tribes, according to this judgment, can be situated at particular points on a scale of social organization. Those who organize themselves in ways that can be easily reconciled with co-called civilized society have rights that survive histories of colonial domination. Those who are lower in the scale, those who act more according to instinct and necessity than precise rights and duties, do not have rights under English law.

Michael Asch has recently argued that the evolutionist model set out in In re Southern Rhodesia finds its way into the more contemporary Canadian Supreme Court decisions, above all in the requirement set down in Justice Mahoney's 1979 judgment in Baker Lake that those seeking legal recognition of their aboriginal title must demonstrate "that they and their ancestors were members of an organized society" 11 at the time of English sovereignty. Asch sees this as meaning more than the reasonable requirement that a group must be more than an arbitrary collection of individuals before it can claim rights; rather it means that, according to the Court, some aboriginal people at the time of contact did not have any form of organization whatever, at least not a form of organization that would allow their descendants to claim aboriginal title. Some aboriginal societies were rudimentary, the behaviour of their members based on instinct and necessity rather than reason and order. ${ }^{12}$ Thus, in Baker Lake, Justice Mahoney finds that Inuit society did not have "very elaborate institutions but (...) a society organized to exploit the resources available on the barrens and essential to sustain human life there. That was about all they could do: hunt and fish and survive." ${ }^{13}$ In other words, the pre-contact social organization of the Inuit was on the lower end of the scale of human development, making them evolutionarily disadvantaged in making claims of aboriginal rights and title. $^{14}$

It is now widely recognized that narrow evolutionist thinking was a central ideological component of policies of assimilation, such as the program of residential education that was pursued with especially disastrous results in Canada. Such policies are a direct outcome of evolutionist paradigms, especially when combined with the goals and ideas of Christian evangelism. If, according to this viewpoint, some people are lower on the scale of human development, suffering from want of religious enlightenment, ingenuity, technology and appreciation of the value of labour, it then becomes a moral duty to instruct, improve and uplift them. The sense of moral superiority that accompanied such thinking was

1 Hamlet of Baker Lake v. Minister of Indian Affairs and Northem Development et al. [1980] 1 F.C. 518 at 557-58, cited in Michael Asch, ibid at 122.

12 lbid.

13 Ibid. at 559.

14 Judicial thinking in the 1970 s no longer shows attachment to universal laws or stages of development. But even though the nineteenth century style universal paradigm is not evident in Baker Lake, the judgment has a lingering attachment to "organization" and "elaborate institutions." 
translated into political action. One of the means of choice for disseminating the fruits of civilization, the Indian residential school, was a form of total institution built upon a self-defeating approach of collective individualization that attempted to shape autonomous citizens through regimented obedience. The widespread realization that such thinking and policies have resulted in institutional abuse, multi-generational suffering and human rights violations has led to political reform and a growing awareness that assimilation policies (at least in their most blatant, institutionally implemented forms) are futile and destructive. This change in approach is reflected in the government of Canada's 1998 Statement of Reconciliation and the implementation of a consultative approach to aboriginal policy, entitled Gathering Strength.

Notwithstanding Asch's perception of the continued influence of evolutionist thinking in Canada's aboriginal law, the government's change of approach to aboriginal policy has also found its way into contemporary judicial decision-making. The central criterion by which aboriginal societies are deemed qualified (or not) for the recognition and exercise of distinct rights is no longer their ability to show some level of sophistication as an organized society at the time before contact. This criterion has been almost entirely replaced by the requirement to show cultural "distinctiveness" at the time before the arrival of Europeans. Justice Lamer outlines such an approach in the majority decision of Van der Peet: "To recognize and affirm the prior occupation of Canada by distinctive aboriginal societies it is to what makes those societies distinctive that the Court must look in identifying aboriginal rights. The Court cannot look at those aspects of the aboriginal society that are true to every human society."15 Rather than (in the tradition of In re Southern Rhodesia and Baker Lake) requiring aboriginal societies to demonstrate "advancement" in the pre-contact period, resulting in the institutional wherewithal to effectively integrate with the legal formalism and institutions of the dominant society, they are now required to demonstrate the opposite: simple subsistence economies, comparatively simple technologies, rudimentary social organization, in other words, those qualities that make them "distinct" from the dominant society, defined principally as the absence of technological and institutional similarity to the dominant society.

According to recent Supreme Court decisions, it is to be expected that defining cultural rights might involve recognition of a "modern form" of an archaic way of life, that the techniques and attitudes that form the most important parts of subsistence pursuits can be adapted to new circumstances, yet still form a significant part of a distinct society. Few would demand that aboriginal hunters use the very same technology and observe the same spirituality of their pre-contact ancestors in order to exercise their

15 Van der Peet, supra note 1 at para. 56 [emphasis in original]. 
subsistence rights. Aboriginal hunters are therefore not required to study the fine art of flint knapping in order to exercise their hunting rights. Technology can change without altering the basic importance of hunting, fishing or gathering. Beliefs and spiritual attitudes can be modified without altering the fundamental cultural significance of subsistence activities. Certainly there is wide acceptance, evident even in court decisions, of the idea that culture cannot be completely unchanged or unchanging. ${ }^{16}$ not only can significant practices leap across gaps of time, to be revived among those who once had let them go; they are also subject to at least some revision and rethinking, adaptation to altered circumstances, above all adjustments to the imposed conditions of modernity. Traditional practices (according to the majority decision in $R$. v. Van der Peet) can be lost or abandoned, but taken up again later. "It does not require an unbroken chain between current practices, customs and traditions and those existing prior to contact."17

The Court, however, does not recognize innovation as an aspect of tradition so much as the sputtering and reigniting of practices that remain fixed within the limits of claims characterized as "modern forms" of centrally significant pre-contact traditions. Innovations that took place after the arrival of settlers are not seen as being integral to tradition. A "frozen in time" approach to culture is thus avoided only in the sense that practices can survive some discontinuity, not in a sense that affirms the importance of adaptation, creativity and innovation. The judicial approach to culture is thus "frozen in time" in the truest sense of the term: it sets limits on change, even in response to challenges to the prosperity and survival of distinct cultures as a whole. ${ }^{18}$

An important issue therefore centres upon the extent to which aboriginal peoples are able to alter their technologies, techniques, attitudes and beliefs without losing their legal rights to cultural protection. At what point do changes to a distinct way of life make it cease to be distinct? Are some peoples no longer recognizable as distinct societies and hence no longer justified in claiming rights beyond those that apply to all Canadians? More specifically, how far must hunting, fishing and gathering practices stay

16 This point is especially clearly expressed the dissenting opinion of Justice L'HeureuxDubé in $R$.v. Van der Peet: "Aboriginal people's occupation and use of North American territory was not static, nor, as a general principle, should be the aboriginal rights flowing from it. Natives migrated in response to events such as war, epidemic, famine, dwindling game reserves, etc. Aboriginal practices, traditions and customs also changed and evolved, including the utilization of the land, methods of hunting and fishing, trade of goods between tribes, and so on (...) Accordingly, the notion of aboriginal rights must be open to fluctuation, change and evolution, not only from one native group to another, but also over time", ibid. at para. 113.

17 Van der Peet, supra note 1 at para. 65.

18 Patrick Macklem makes a similar observation when he writes, "By protecting only practices, customs, and traditions integral to Aboriginal cultures, the Court treats Aboriginal cultural difference as the only aspect of indigenous difference that possesses constitutional significance." Patrick Macklem, Indigenous Difference and the Constitution of Canada (Toronto: University of Toronto Press, 1992) at 61. 
within social and technological limits in order to be legally protected? Is there an assimilationist cut-off point to cultural rights?

In several recent decisions, Canada's Supreme Court has required aboriginal peoples to demonstrate much more than mere possession of a general right to fish, hunt or gather. They have been obliged to prove such rights on a species-by-species basis, to demonstrate that their harvesting activities are integral to their "tradition, custom, practice or law," dating from before the time of contact between their ancestors and Europeans. Justice Lamer C.J., for example, takes this position in $R$. v. Van der Peet, a case involving salmon fishing rights: "Participation in the salmon fishery is an aboriginal right because it is an 'integral part' of the 'distinctive culture' of the Musqueam. This suggestion is consistent with the position just adopted; identifying those practices, customs and traditions that are integral to distinctive aboriginal cultures will serve to identify the crucial elements of the distinctive aboriginal societies that occupied in North America prior to the arrival of Europeans." ${ }^{\prime 19}$ The Supreme Court also applied this test in $R$. v. Gladstone in connection with the Heiltsuk practice of harvesting herring spawn on kelp: "the appellants in this case must demonstrate that their attempt to sell herring spawn on kelp was an element of a practice, custom, or tradition integral to the distinctive culture of the Heiltsuk Band."20 But what if the Musqueam did not fish salmon at the time before contact with Europeans? What if the Heiltsuk harvest of herring spawn on kelp was a post-contact innovation? Suppose these practices were borrowed from neighbouring aboriginal peoples, or even from Europeans, thus becoming part of "distinctive aboriginal societies" some time after contact. Would this rule out salmon fishing or gathering herring spawn as part of legitimate aboriginal livelihoods and ways of life? Apparently it would. The approach taken by the Court in $R$. v. Van der Peet implies that if an aboriginal people did not fish salmon at the time before contact with Europeans, or at the very least at the time of the assertion of sovereignty by Britain, then these same people would have no aboriginal right to fish salmon. This would apply even if they were fishing other species at an earlier period in history and took on salmon harvesting as a meaningful extension of their longstanding subsistence practices. It would also apply to innovative responses to dire necessity brought about by the dwindling of their resource base as a result of European encroachment.

Judicial resistance to cultural change in aboriginal societies appears to be a result of limitations on the exercise of economic and political sovereignty. The Court, for example, is not at all friendly toward aboriginal management and control of their subsistence activities. Harvesting rights have been separated out from aboriginal economies and ways of life as meriting protection within the limits of federal regulation. In $R$. v. Marshall, for

Van der Peet, supra note 1 at para. 45.

R. v. Gladstone, [1996] 2 S.C.R. 723 at para. 22. 
example, "The Mi'kmaq treaty right to participate in the largely unregulated commercial fishery of 1760 has evolved into a treaty right to participate in the largely regulated commercial fishery of the $1990 \mathrm{~s}^{\prime 21}$; and "[R]esponsibility [for conservation of resources and other 'compelling and substantial public objectives'] is placed squarely on the Minister and not on the aboriginal or non-aboriginal users of the resource." 22 Subsistence rights have therefore been fractured; the act of harvesting "in a traditional manner" has been separated from social responsibility for the harvest as a whole.

The Court's curtailment of aboriginal rights of harvest regulation is consistent with the notion of incompatibility with Crown sovereignty, expressed with particular poignancy in M.N.R. v. Mitchell. Ruling on the right of the Mowhawks of Akwesasne to bring goods into Canada from the U.S.A. for trading purposes without paying duty, the Court argued that to be afforded legal protection as an aboriginal right, distinct traditions cannot be incompatible with the Crown's sovereignty: "important as they may have been to the Mohawk identity as a people, [for example,] it could not be said that pre-contact warrior activities gave rise under successor regimes to a legal right under s. 35(1) [of Canada's Constitution] to engage in military adventures on Canadian territory." ${ }^{23}$ Pre-contact aboriginal practices are therefore subject to the criterion of compatibility with the Crown's sovereignty as a central prerequisite of cultural rights.

Recent majority decisions of the Supreme Court thus take a selective, "frozen rights" approach to culture. The way this is qualified-for example in $R$. v. Van der Peet, by citing the concept of continuity and the fact that a practice can be resumed after an interruption-does not significantly alter the Court's "frozen" approach to cultural change. This approach minimizes, overlooks or excludes the fact that all human societies innovate and adapt practices from others (including dominant societies), while retaining their essential distinctiveness. Making rights conditional upon basic continuity with pre-contact practices is an onerous requirement inconsistent with the rapid pace of change experienced today by all human societies.

These general observations have significant implications for the Supreme Court's approach to aboriginal rights. The decision at any point in the history of an aboriginal people about what species of fish to harvest or what natural resources to exploit is based on circumstances that existed at that time; and the choice to fish one species and not another at any given point in the history of an aboriginal people should not affect aboriginal rights today. ${ }^{24}$ Yet the "species-by-species" approach to aboriginal resource rights involving an onerous test of cultural purity has been clearly established by

21 Marshall, supra note 5, Motion for Rehearing and Stay at 2.

22 Marshall, supra note 5 at para. 40.

23 M.N.R. v. Mitchell, [2001] 1 S.C.R. 911 at para. 153.

24 I am grateful to Paul Joffe for bringing this "species-by-species" approach to aboriginal subsistence rights to my attention, thus providing a key stimulus for my research on this topic (pers. comm., Nov. 14, 2000). 
the Supreme Court of Canada and will likely influence the outcome of other cases heard by Canadian courts. ${ }^{25}$

A consideration of how the Court defines culture with the clarity demanded of judicial decision-making is the key to understanding how recent decisions concerning aboriginal rights have been arrived at and what their implications are for aboriginal peoples. The judges who make use of the concept of culture in their decisions do not take it upon themselves to develop or elaborate new theoretical paradigms. Their task is much more straightforward. They are required, as they see it, to resolve disputes by acquiring information and applying the law. Their concern is more with facts than ideas. In cases that involve aboriginal rights, their orientation is more in the direction of the specific circumstances in which those rights were acquired or recognized by England or Canada than towards the theoretical frameworks of anthropology or history. Even when the Court is required to consider issues that relate, in international human rights parlance, to "the right, in community with other members of their group, to enjoy their own culture," 26 the first order of business, as the judges tend to see it, is to "find the facts."

If judges have sometimes rendered decisions that relate to cultural rights, where does their concept of culture come from? Given that they did not develop this concept themselves, the most obvious answer would be that they acquired their particular usage from the experts who did, from the anthropologists and historians who, in their respective disciplines, have developed sophisticated, debated and ever-changing approaches to group identity and human differences. But when we examine the judicial approach to culture more closely, we come to realize that it does not fit perfectly with any anthropological or historical approach. The judicial approach to aboriginal cultures in Canada has its own unique qualities, some clearly derived from its concern with "facts," with information from academic experts and with human rights standards in international law, others likely based upon popular notions (or prejudices) concerning aboriginal culture and aboriginal rights.

\section{The Culture of Experts}

To arrive at decisions about aboriginal cultures that are not merely reflections of public prejudices and private interests, courts frequently make

25 Prominent among these are the decisions yet to be made by the courts in the Atlantic Provinces concerning lobster fishing by members of such communities as Burnt Church (New Brunswick) and Indian Brook (Nova Scotia). The ongoing contest in the Atlantic region between Aboriginal peoples asserting their rights of subsistence and the organized interests of non-Aboriginal commercial fishermen also has important implications for the elaboration of Aboriginal rights of self-determination in Canada, evident in the way the Supreme Court has recently sought to subsume Aboriginal subsistence rights under the authority of the federal government.

26. International Covenant on Civil and Political Rights, 19 December 1966, 999 U.N.T.S. 171, art. 27 [ICCPR]. 


\section{Ronald Niezen}

use of expert witnesses, those professional anthropologists, historians and others who possess specialized knowledge about aboriginal ways of life within their respective disciplines. How (if at all) are the approaches taken by those scholars who elaborated the concept of culture reflected in judicial decisions concerning aboriginal rights? And in what ways do the courts ignore or fail to take into account the perspectives developed by scholars specializing in the history, geography, languages and customs of aboriginal peoples?

The recent judicial conceptualization of aboriginal culture relies on a scholarly approach to culture that is far more specialized than the broad, value-laden paradigms of evolutionism. Consistent with the rejection of evolutionist and assimilationist ideas, the judicial reference point for determining the scope of aboriginal rights has in recent decades been narrowed down to specific practices of the pre-contact ancestors of contemporary aboriginal peoples.

The courts draw upon a wide array of scholarly expertise in their effort to acquire a greater understanding of aboriginal cultures and thus to be able to rule fairly in particular cases. In reaching some judgments, they are supported by the work of researchers whose orientation toward culture continues to emphasize the rigorous study of particular cultures and distinct culture areas. Historians are usually able to provide some background to the contexts in which treaties were negotiated; and those working within the subdiscipline of ethnohistory can present a picture of an aboriginal society as it existed several centuries ago-how people survived, the values they held, and the motives behind their interaction with Europeans; anthropologists specializing in ethnography can portray current practices and beliefs in a detailed and systematic way (some would say too detailed and systematic, resulting in "objectification" and creation of an alien "Other," but this is not a debate taken up by the courts); linguists can provide insight on a people's past migrations using the methods of lexical reconstruction, etc. Willing or not, courts can easily become immersed in a considerable and occasionally imposing mass of information relating to particular aboriginal societies or even particular practices of one recognized society.

A problem that applies particularly to testimony from ethnohistorians arises from the fact that it is often equivocal and uncertain, qualities that stem from gaps in historical records and unreliability of written sources or the biases of "informants"; and even where the material is relatively complete and trustworthy, indeterminate testimony can result from the complexity of the flux and reflux in daily life, especially in interactions between Natives and Europeans, and from the many strands that go into extraordinary events, such as the negotiation of a treaty or the establishment of a permanent settlement.

This is not to say that Canada's courts always accept or even take into consideration the knowledge and guidance of such experts. In a ruling 
subsequently overturned by the Supreme Court in Delgamuukw v. British Columbia, for example, Justice McEachern at the British Columbia Supreme Court heard 374 days of evidence and argument, much of it from experts in genealogy, linguistics, archaeology, anthropology, and geography, aimed mainly at assessing the claims of the Gitskan to historical use and "ownership" of traditional territories. ${ }^{27}$ Justice McEachern rejected much of this expert testimony as biased in favour of the aboriginal claimants, prompting the Supreme Court, in its appeal ruling, to elaborate new standards for the inclusion and assessment of aboriginal expert testimony. ${ }^{28}$

Professional historians have in turn been critical of the courts for not taking into consideration many of the cultural and historical nuances they wish to communicate. A barrage of articles by Canadian ethnohistorians subjected court decisions to careful scrutiny and found a tendency in judicial decisions concerning aboriginal rights to overlook the contextual nuances of key documents and the frailties of their sources. ${ }^{29}$ The courts have stirred up the disapproval, and occasionally the resentment, of specialist scholars by flouting the rules of academic engagement. Judicial decisions have seemingly ignored social and historical complexity, and occasionally offended those who wish to convey it. Whereas the courts prefer information that is as close as possible to "yes" or "no" and "black" or "white," scholars providing testimony tend to offer "but," "maybe" and shades of grey.

The courts have shied away from such uncertainty, and as a result the courts' perceptions of aboriginal culture are shaped by an inadequate understanding of anthropological approaches to culture and of the expert witnesses' own limitations in understanding the people they study. An expert well versed in a particular way of life might be able to tell if his or her research subjects fished salmon around the time of contact; but they are unable to say with much certainty whether or not the practice is culturally relevant today. Cultural values are by their very nature subjective. The Supreme Court has argued in response to criticism from scholars that it does not have the time to delve into specialized testimony and material with the kind of thoroughness necessary to resolve disagreements among the experts. "The reality, of course, is that the courts are handed disputes that require for their resolution the finding of certain historical facts. The litigating parties cannot await the possibility of a stable academic consensus. The judicial

27 See Robin Fisher, "Judging History: Reflections on the Reasons for Judgment in Delgamuukw v. B.C." (1992) British Columbia Studies 45.

28 See Culhane, supra note 7 , for a detailed account of this testimony and of Justice McEachern's decision.

29 See, for example: Donald Bourgeois, "The Role of the Historian in the Litigation Process," (1986) Canadian Historical Review. 67:2: 195-205; Dickason, G.M. and R.D. Gidney, "History and Advocacy: Some Relflections on the Historian's Role in Litigation" (1987) 68:4 Canadian Historical Review 576-85; Arthur Ray "Creating the Image of the Savage in Defence of the Crown: The Ethnohistorian in Court" (1990) 6:2 Native Studies Review 13. 
process must do as best it can." ${ }^{30}$ The kind of testimony the courts are looking for is that which provides a clear picture of the context in which a controversy is situated, information that does not get ahead of the courts in passing judgment by presenting slanted views or carefully selected information but that prepares the ground for the courts by turning over new information-"facts."

Without the focal point provided by treaty documents, however, expert testimony concerning aboriginal culture tends to be particularly equivocal. There is a contradiction inherent in making cultural rights contingent upon specificity and the comfortable support of "facts." Over-reliance upon expert witnesses in cases involving cultural rights can easily lead to an unwarranted emphasis on particulars-the kind of technology used by a peoples' ancestors, the species they fished and hunted, the avenues through which they traded, and so on-details that limit the scope of innovation and adaptation allowed by the courts. Questions of broad applicability, such as the importance of cultural change in the context of European settlement and expansion, the attachments to hunting and gathering that continue through the process of adaptation, and the importance of a secure identity for a people's social and economic well being - these are not the kind of issues that courts have tended ask experts to elaborate on. Instead, they have been asked to provide what they are good at providing: specific information concerning details of a people's life in the past, such as whether or not they fished salmon or gathered herring spawn from kelp.

The obvious way for the courts to address such problems is to go directly to the source, to solicit the knowledge and opinions of non-professional "experts" of aboriginal origin, the people most experienced with, and affected by, the issues being considered. Those who profess attachments to such things as subsistence practices or rituals can themselves best provide evidence of their cultural significance. Courts have thus also occasionally sought the expert opinions of aboriginal people themselves, those selected to represent their societies and express, in what is for some a formal and alien court setting, their core beliefs, values, and practices.

Cultural rights thus increase the salience of expert testimony from those aboriginal people affected by the issues being considered by the courts. At the same time, it increases the potential for such testimony to be awkwardly solicited, misunderstood, ignored, scorned or rejected. In the 1972 "James Bay Trial," for example, in which Cree and Inuit plaintiffs sought an injunction in Quebec Superior Court to halt construction on the La Grande hydroelectric project, the degree of specificity sought by the Court was clearly at odds with the kind of testimony that Cree hunters and fishermen were able to offer. James O'Reilly, representing the Cree and Inuit, complained that, "the cross-examiners were wanting the Indian witnesses to 
be like computers, to produce all sorts of figures and documents that should more properly be sought elsewhere." 31 The judicial search for "facts" sometimes has an uncomfortable relationship with the personal experience of elders, many of whom grew up in an oral society. More recently, however, the courts seem to be fine-tuning their ability to sensitively acquire and make use of testimony from aboriginal experts. In the 2001 decision M.N.R. v. Mitchell, for example, the Court observed that the oral histories provided by elders was "confirmed by archaeological and historical evidence, was useful and the trial judge did not err in finding the respondent's evidence to be credible and reliable." ${ }^{32}$

\section{Cultural Rights in International Law}

International law has long been a source of domestic law reform in Canada and therefore a potential source of ideas about the legal standing of indigenous cultures. James Anaya, in Indigenous Peoples in International Law, approaches international law as a source of judicial, political and social reform, a way to influence domestic law and alleviate the injustice and adversity indigenous peoples commonly experience at the hands of nationstates. "International law, although once an instrument of colonialism, has developed and continues to develop, however grudgingly or imperfectly, to support indigenous peoples' demands. ${ }^{, 33}$ If the Supreme Court of Canada is misguided in its approach to culture, does international law provide an alternative approach through existing or emerging human rights standards? At the very least, it appears that the process of formulating such an approach is well under way.

The kind of issues referred to by Canada's Supreme Court as "elements of a practice, custom or tradition integral to the aboriginal community's distinctive culture" ${ }^{34}$ are most commonly dealt with in international law as the rights of peoples to their own subsistence and the rights of peoples to self-determination. These rights are elaborated in a number of instruments devoted specifically to indigenous peoples, such as the ILO Convention (No. 169) concerning Indigenous and Tribal Peoples in Independent Countries, the draft Inter-American Declaration on the Rights of Indigenous Peoples and the draft United Nations Declaration on the Rights of Indigenous Peoples. The most direct source of guidance in international law concerning cultural rights, however, has come from The Human Rights Committee, which has handled several cases (directly analogous to those in which

31 Cited in Boyce Richardson, Strangers Devour the Land (Vancouver: Douglas \& McIntyre, 1991) at 41.

32 Mitchell, supra note 23 at 2.

33 James Anaya, Indigenous Peoples in International Law (Oxford: Oxford University Press, 1996) at 4. I discuss the connection between human rights and indigenous identity in The Origins of Indigenism: Human Rights and the Politics of Identity (Los Angeles: University

Mitchell, supra note 23 at 3. 
Canada has defined its approach to aboriginal culture) under the Optional Protocol to the International Covenant on Civil and Political Rights (ICCPR). This procedure excludes collective grievances, and aboriginal peoples and organizations have therefore not been able to use it to further their pursuit of self-determination, but individuals have nevertheless been able to use the Optional Protocol to defend themselves against what they see as violations of their cultural interests. Complaints of this kind are based upon Article 27 of the ICCPR: "In those States in which ethnic, religious or linguistic minorities exist, persons [i.e. individuals] belonging to such minorities shall not be denied the right, in community with the other members of their group, to enjoy their own culture, to profess and practise their own religion, or to use their own language. ${ }^{35}$ Although the Human Rights Committee's interpretation of Article 27 does not directly address the ambiguities of the culture concept, it does go some distance toward reconciling distinct peoples' attachments to their own subsistence with the need of all societies to change in response to unforeseen opportunities and obstacles.

Article 27 of the ICCPR was first invoked by the Human Rights committee in 1984 as a remedy against unwanted development in Ominayak v. Canada, a case involving aboriginal land rights and cultural rights in northern Alberta. In his original submission to the Human Rights Committee, Chief Bernard Ominayak of the Lubicon Lake Band argued that his community's rights of self-determination (under article 1, paragraphs 1 to 3 of the ICCPR) were violated when the Canadian government allowed the provincial government of Alberta to expropriate the ancestral territory of the Lubicon Lake Crees for the benefit of private corporate interests (in the form of leases for oil and gas exploration and timber cutting). The Committee did not accept the complaint as it stood. It reasoned that an individual could not claim a right of self-determination and therefore could not argue that this right had been violated. ${ }^{36}$ The Committee found, however, that many of the issues surrounding the negative consequences for the Lubicon Cree of oil and gas extraction and timber cutting fell within the purview of Article 27 and concluded that the government of Canada had failed to rectify the historical inequities that continued to threaten the way of

35 ICCPR, supra note 26.

36 "[T]he Committee observed that the author [Chief Ominayak], as an individual, could not claim under the Optional Protocol to be a victim of a violation of the right of self determination (...) which deals with rights conferred upon peoples, as such." Views of the Human Rights Committee under article 5, paragraph 4, of the Optional Protocol to the International Covenant on Civil and Political rights. UN doc. No. CCPR/C/38/D/167/1984, at para. 13.3. Against the argument that this approach by the Committee renders article 1 of the ICCPR unenforceable since only individuals can submit complaints under the Optional Protocol, the Committee suggested that "there is no objection to a group of individuals, who claim to be similarly affected, collectively to submit a communication about alleged breaches of their rights [under article 1]", ibid. at para. 32.1. This still indicates a tension between the individual rights orientation of the Optional Protocol and the collective rights inscribed in article 1 of the ICCPR. 
life and culture of the Lubicon Lake Band. In making this decision, the Committee did not deal with the question of what constitutes a distinct culture, probably because the communications by Chief Ominayak made it patently clear that the Lubicon Cree were a society that "continues to maintain its traditional culture, religion, political structure and subsistence economy" in ways highly dependent upon continued use of traditional lands, ${ }^{37}$ and this point was not disputed by the government of Canada. Ominayak v. Canada therefore establishes the applicability of Article 27 to aboriginal individuals whose communities experience the deleterious effects of unwanted development, but it does not address the issue of cultural adaptation and change, of what constitutes a distinct way of life in the context of encroaching modernity.

The Human Rights Committee responded more directly to the "frozen in time" approach to cultural rights in Ilmari Länsman et al. v. Finland. In this communication, the Samis of northern Finland complained that stone quarrying by the Arctic Stone Company and the road construction associated with the enterprise were interfering with reindeer herding and desecrating a sacred place at the site of the quarry on mount Etelä-Riutusvaara. The Committee found that the extent of the development did not prevent the Samis from practicing their livelihood or religion. At the same time, however, it rejected the government of Finland's approach to culture. It pointed out that a culture, in order to be afforded protection, does not have to be narrowly construed as "traditional." "The right to enjoy one's culture," the Committee states, "cannot be determined in abstracto but has to be placed in context. In this connection, the Committee observes that article 27 does not only protect traditional means of livelihood of national minorities (...) Therefore, that the [Samis] may have adapted their methods of reindeer herding over the years and practice it with the help of modern technology does not prevent them from invoking article 27 of the Covenant."38 Environmental destruction by state-sponsored extractive industries beyond the limits in which reindeer herding could continue as a culturally significant activity would constitute a violation of the Samis' rights under the Optional Protocol of the ICCPR, regardless of whether or not the distinctive qualities of the Sami way of life could be seen as having a link with ancestral practices.

37 Ibid. at para. 2.2. In this context, an appended submission by an individual member of the Committee, Mr. Nisuke Anudo, is informative. His dissenting concern appears to be that the right to enjoy one's own culture could be interpreted narrowly to exclude considerations of change. He argues that "outright refusal by a group in a given society to change its traditional way of life may hamper the economic development of the society as a whole." This individual opinion thus legitimately points to issues of adaptation and change as important components of cultural rights, but it overlooks considerations of selfdetermination, leaving it possible to argue that forcing a people to change their way of life through unwanted extractive industrial activities is not a violation of their cultural rights.

38 Views of the Human Rights Committee under article 5, paragraph 4, of the Optional Protocol to the International Covenant on Civil and Political Rights, UN doc. No. CCPR/C/52/D/511/1992, para. 9.3 [Emphasis in original]. 
The Canadian judiciary's species-by-species approach to aboriginal rights of subsistence can therefore be seen as eroding a variety of human rights and ultimately compromising the ability of aboriginal communities to be self-sustaining. Martin Scheinin (a current member of the Human Rights Committee) links cultural rights (expressed principally in Article 27 of the International Covenant of Civil and Political Rights) to the right to selfdetermination, rights of participation, property rights, and the right to private life. He finds that the notion of culture in Article 27, as expressed by the Human Rights Committee, "is not frozen but that the provision may be invoked as support for an indigenous way of life that has a historical link to the traditional life style but has, nevertheless, undergone transformations over decades and centuries." ${ }^{39}$ Scheinin expresses concern that the 'freezing' approach to aboriginal rights in Canada "may become fatal in a situation in which the sustainability of traditional nature-based economic activities has been destroyed and the members of an indigenous community are living on unemployment or welfare benefits. The ultimate outcome of affording protection only to economic activities that were practiced 'at the time of contact' will, in many cases, be the extinction of the culture."

\section{Popular will}

There can be little doubt that judges are influenced in their decisions by what is loosely termed the popular will-ideas, including stereotypes and prejudices, that reflect widely held convictions, or "common sense" ideas that often (mis)inform judicial decisions and motivate political action. Such popular will ideas include those articulated by interest groups competing with aboriginal peoples and communities over resources. To these groups, aboriginal culture is commonly seen as defunct, a thing of the past, trucked out in an effort to gain the upper hand in resource competition. But there are also representatives of popular will with more generous views of aboriginal culture, those who see it as one of the last remaining hopes of cultural diversity and ancient ecological wisdom. This is an approach to aboriginal culture that is pervasive in much the same way that evolutionism was pervasive in the nineteenth century. A variety of (often contradictory) popular ideas about aboriginal peoples can be seen as influencing the way judges think about cultural rights. Both the unfriendly prejudices of those who see themselves as being in competition over resources with aboriginal peoples and the cultural romanticism and preservationism of others who more often support aboriginal interests as part of a wider agenda of environmental and cultural stewardship have coalesced into non-

\footnotetext{
39 Martin Scheinin, "The Right to Enjoy a Distinct Culture: Indigenous and Competing Uses of Land" in Theodore Orlin, Allan Rosas \& Martin Scheinin, eds., The Jurisprudence of Human Rights Law: A Comparative Interpretive Approach (Turku/Åbo: Institute for Human Rights, Åbo Akademi University, 2000) 159 at 169.

lbid. at 197-98.
} 
governmental organizations that attempt to influence public perceptions, government policies and judicial decision making. As a significant part of civil society, organizations promoting ideas about aboriginal culture have an influence on the perspectives adopted by most Canadians. By broadly affecting the way people think about aboriginal societies, they in all likelihood have an oblique influence on the approach to aboriginal culture taken by the courts. The two examples of popular orientations to aboriginal culture that follow are in some respects at opposite ends of a spectrum of opinion:

\section{Aboriginal Peoples as Environmental Sages}

Ironically, one of the impediments to aboriginal control over natural resources could well be the prevalence of the idea that aboriginal peoples are living representatives of environmental wisdom, that at the very least they have the potential to put into practice a form of subsistence and a form of life based upon intimacy with and respect for the natural world. The forestbased subsistence native peoples once practiced, and today possess remnants of, is a source of knowledge and spiritual understanding all can benefit from. Paleolithic knowledge, or what we can today understand of it, stands as an alternative to the project of modernity, industrial exploitation, destruction, and "improvement" of entire forest ecosystems.

Max Oelschlaeger, for example, adopts the perspective of "the Paleolithic counterrevolutionary," who sees the strongest possible contrast between the environmental sagacity and gentleness of pre-agricultural society and modern industrial society's self-destructive hubris, a taming of all things wild and free, and a uniform lifestyle of social intensity in the subjection of nature for the projects of industry and civilization. "The modern project, which has long promised the total humanization of the earth's surface, is paradoxically destined to fail through its own success." ${ }^{41}$ Paleolithic people, by contrast, "lived comfortably in the wilderness, much as the Inuit on the polar ice or the Kalahari Bushmen in Africa, and they probably had plenty of nourishing food., ${ }^{, 2}$ Poverty is the outcome of civilization's ambitions, the result of intense living, competition, and a loss of harmony with the natural world, a loss of Paleolithic-style "intelligence." And all people of the world can prosper by a return to the values of their remote ancestors.

The basic goal of cultural preservationists is to improve their own lives and provide a model for wider social and spiritual reform by looking to the past for the uncorrupted essence of humanity. But the kind of wisdom that contemporary indigenous peoples are able to offer depends upon their own ability and willingness to maintain the Paleolithic lifestyle and share it with

\footnotetext{
41 Max Oleschaeger, The Idea of Wilderness: From Prehistory to the Age of Ecology (New Haven: Yale University Press, 1991) at 8.

42

Ibid. at 14 .
} 


\section{Ronald Niezen}

others. This is by no means a sure thing. Too often, according to this approach, Native people share in the degradation, rootlessness and alienation of modernity. Paleolithic wisdom only occasionally survives in the form of cultural artifacts, or in the form of aboriginal cultures as living collective artifacts.

A corollary of this attitude toward aboriginal cultures is suspicion, rejection or misjudgment of their adaptation to conditions of modernity. It emphasizes the ways that aboriginal peoples differ from industrial, bureaucratic society, differences that have the potential to instruct and improve others. On this view, new hunting technologies, means of transportation, electronic communication, village settlement and bureaucratic organization threaten to upset the delicate balance between humans and the natural world, erode the simple material foundations of forest spirituality, and change hunting and gathering from a way of life to a way of making a living. There is a small step from this approach to cultural change in aboriginal societies to the view that cultural rights should not apply to practices and traditions that are extrinsic to these societies, especially not those borrowed or adapted from the technologies and values of industrial society.

There is an interesting and puzzling consistency between the approaches to aboriginal culture of those whom we might call "preservationist cultural counterrevolutionaries" and the Supreme Court judgment in $R$. v. Van der Peet. Both see the essence of aboriginal culture as deriving from the Paleolithic way of life of the pre-contact period. Both to some degree reject aboriginal cultural borrowings from industrial North Atlantic societies. And both are consistent with the premise that those aboriginal societies that stray too far from the path of Paleolithic values and technology are unworthy of the rights and respect due to distinct societies.

It would probably be going too far to say that the Supreme Court justices therefore share the values of romantic cultural preservationists. Rather each, in different ways and for very different reasons, is suspicious of (and at times rejects) those forms of aboriginal culture that do not correspond with an ideal of untainted, original lore and life. Cultural preservationists have censured aboriginal communities for spiritual and ritual secrecy, for unwillingness to share with others the attitudes and methods of harmony with nature. The wisdom of the elders is seen as universal in application, and the unwillingness of some to share it openly with others is condemned as misguided pride or, more generously, as an unfortunately broad application of ritual secrecy. Aboriginal societies that refuse to share cultural knowledge with an eager non-aboriginal audience cut themselves off from the opportunity to make their special understanding of the natural world part of a wider human heritage of Paleolithic wisdom. Worse than the refusal to share is the willingness of aboriginal societies to dilute the purity of their ancestral knowledge with borrowings from non-Native culture. 
Westernization is a corruption of essential truths that can and should be made part of everyone's life, or that should at least be available to those that seek spiritual improvement. These truths then become not just inconveniently withheld, but permanently inaccessible, lost to humanity, diminishing forever the variety of human possibilities.

Not only are the courts and the cultural preservationists essentially similar in their preference for selected qualities of pre-contact societies as the model for contemporary expressions of "tradition," the outcome of their cultural censorship is virtually the same. Aboriginal peoples are not "authentic" if they do not in some essential ways faithfully represent a sanitized Paleolithic ideal. When they stray too far from this traditional model, they can no longer command sympathy or protection. The main difference between the two approaches is in the features of ancestral aboriginal society seen to be worthy of attention. The cultural preservationists stress the importance of spiritual values attached to a simple lifestyle whereas the courts look most carefully at the sovereignty implications of particular practices that have become the foci of disputes with the State.

\section{Paleolithic Destructiveness and Popular Prejudice}

There is an emerging consensus among historians of Native North American societies that the popular images of Indians as "keepers of the land" who "walk in a sacred manner" with Mother Earth are largely products of western ecological self-criticism, fantasies spun in support of very contemporary ideas about how humans should live in the natural world. Those who lived in North America before European contact were not ecologically self-conscious, at least not in the ways propounded by environmentalists, but held strikingly different ideas about their place in the world and their relationships with animals. Their ecologies, according to Shepard Krech, for example, were premised upon belief in animal reincarnation, on theories of animal behaviour and animal population dynamics that are alien to the approach of scientific conservation. Above all, the ideas of reincarnation widely held by Native hunters, Krech convincingly argues, did not discourage waste and overkill. "Animal populations declined from lack of respect, not over hunting"; and Native peoples only later embraced the systematic regulation of game "as alternative ways of explaining [and responding to] the decline of deer, beaver, and other animals as a result of western commodification." ${ }^{43}$

But there are also non-scholarly ideas that act in opposition to cultural romanticism, ideas that begin with the premises that aboriginal peoples have never been environmental sages and the only thing keeping them from perpetrating the wholesale destruction of their forests and rivers is their

43 Shepard Krech III, The Ecological Indian; Myth and History (New York: W.W. Norton \& Company, 1999) at 213. 
relative lack of power. This view, expressed, for example, by New Brunswick's non-aboriginal fishermen who are in competition over the lobster fishery with the Native community of Burnt Church, sees the federal government's reluctance to join in the fray over a lucrative resource, not as a passive recognition of treaty promises, but as capitulation to unreasonable demands. If aboriginals are to fish, "it has to be under the same regulations and conditions as the rest of us." 44

Aboriginal peoples should therefore be prevented from exercising control over natural resources if Canadians as a whole are to enjoy the benefits of effective, centrally administered environmental management. How can aboriginals be trusted to manage the large areas they claim as ancestral territory? Rather than let the Indians bring in lobster traps or bulldozers beyond the reach of public accountability, let sophisticated government agencies or environmentally sensitive corporations take charge of regulating fish and game or conquering and taming the North. Opponents of aboriginal resource control occasionally invoke a relatively new popular prejudicewhich represents aboriginal peoples as environmentally rapacious-in an effort to call their motives and integrity into question.

This dimension of the popular will has implications for judicial recognition (or limitation) of aboriginal rights and can be seen as a possible source of influence behind the "frozen rights" approach to aboriginal rights of subsistence. In $R$. v. Van der Peet, as we have seen, the Court holds that an activity does not have to precisely mirror the pre-contact past, but may comprise "an exercise in modern form of (...) pre-contact practice," to be protected as an aboriginal right. ${ }^{45}$ Given this approach, could a native community legally put into practice (in modern form of course) a hunting regime that brought back the importance of reincarnation beliefs and that put into practice periodic intensive killing of game animals? No, because aboriginal practice must also be reconciled with the sovereignty of the Crown, which, according to the explanatory amendment to $R$. v. Marshall, is the legitimate task of the federal Minister responsible, not of aboriginal peoples.

The same limitation would arise whenever aboriginal peoples or communities put into practice any other form of autonomous hunting regulation and game control. Cultural rights include some subsistence practices but do not extend to the right to manage that subsistence. A basic difficulty in the Supreme Court's approach to aboriginal culture, therefore, arises from the separation of "modern forms" of subsistence practice from subsistence regulation or management. These are inseparable components of all economic systems, but in the approach to aboriginal culture expressed in $R$. v. Marshall they do not as a whole form part of what aboriginal peoples

44 Chris Morris, "Non-native fishermen in NB call for immediate end to Burnt Church fishery" Canadian Press (17 September 2001). 
can claim as a component of their distinct rights. $R$. v. Marshall does not so much reconcile aboriginal rights with the sovereignty of the Crown as much as it imposes the will of the Crown upon distinctive aboriginal activities. Subsistence activities thereby lose the quality of being protected as distinct rights; they become privileges to be granted and taken away by the Minister at will.

What the Court manages to achieve with its regime of cultural rights, whether intentionally or not, is a remarkable accommodation and synthesis of popular prejudices. Those who wish to see unadulterated Paleolithic wisdom in the way contemporary aboriginal hunters and fishermen practice their harvest could well be gratified that the Court looks back to the supposedly simple, unhurried, environmentally balanced hunting and gathering ways of life of prehistoric peoples for examples of the rights to be enjoyed by their descendants. For those who, on the contrary, see aboriginal peoples as environmental cardsharpers, restricted only in their control over resources, there is comfort to be taken in the Court's tight focus on specific rights to particular species handed down from an explicitly defined time in the past or derived from unambiguous treaty provisions.

\section{Conclusion: Difference-Blindness vs. Aboriginal Rights}

The inconsistencies between various notions of aboriginal culture reflect a central ambiguity in the Court's use of social theory. As Canada's history of assimilation policy illustrates, there can be a strong tendency in liberal societies to assert, sometimes in misguided and destructive ways, the equal dignity and rights of all citizens, with strong legal and political emphasis on nondiscrimination, prohibition of any differences in life opportunity based on collective differences: race, religion, sexual orientation, gender, age, and so on. The struggle for such individual rights of equal dignity remains in some ways incomplete, but the fact of this incompleteness at the same time sharpens the effort to advance the state's blindness to differences. The courts can be seen as participants in the project of universalizing a form of liberal individualism that seeks to eliminate social differences grounded in distinct rights.

But the courts are at the same time faced with collective claims that lead to recognition of cultural distinctiveness and distinct rights, played out in what Charles Taylor calls the "politics of difference," an approach to collective rights in which "what we are asked to recognize is the unique identity of this individual or group, their distinctness from everyone else."46 Taylor suggests that this orientation to rights is a direct outcome of the liberal emphasis on equality, the main difference being that the politics of difference stresses collective dignity, the infusion of nondiscrimination with

46 Charles Taylor, Multiculturalism, ed. by Amy Gutmann (Princeton: Princeton University Press, 1994) at 38. 
a new emphasis on group identity in which distinctions are made on the basis of differential regimes of rights.

Aboriginal rights sit squarely in the middle of this tension. In questions concerning treaty-supported resource use, land claims and cultural rights, knowledge about the aboriginal society in question at the time before contact with Europeans becomes a source of guidance for decisions that are often essentially about the allowable limits of self-determination. Treaties are clearly a form of legal recognition of collective difference that affirm and formalize rights not enjoyed by other Canadians. Aboriginal land rights are a form of "ownership" attached to distinct rights to resources and rights of self-government. And aboriginal cultural rights involve legal protections of distinct ways of life, and the more implicit recognition that such protections are necessary for the health and survival of aboriginal peoples. These regimes of aboriginal rights, some of which predate Canadian confederation, cannot be reconciled with a narrow approach to equal dignity and nondiscrimination. In every case involving aboriginal rights, therefore, the Court faces a delicate task of balancing the honour of the Crown with a form of liberalism inhospitable to differentiated rights. It has approached aboriginal rights in a way that reduces the effect of their distinctiveness, isolating them with sharp focus and specific content, removing them as far as possible from the context of self-determination.

It is possible to see this tension expressed in the way the Court has elaborated its definition or "test" of aboriginal cultural rights. In this test, culture is separated from collective agency. Recognition of distinct cultural practices is tightly focused, eked out in a pattern of species-by-species rulings. And above all, cultural rights are separated from aboriginal rights of self-determination. As far as possible, the Court has contained the collective dimensions of aboriginal rights within the close confines of liberal individualism.

The majority opinion of the Supreme Court in R. v. Van der Peet, for example, reveals the main features of the Court's current approach to aboriginal culture, the highlights of which are as follows: At the time of contact between aboriginal peoples and the British Crown, the aboriginals "lived on the land in distinctive societies, with their own practices, customs and traditions." To be protected by an emerging regime of rights in Canadian law today, these practices, customs, and traditions must be "of central significance to the society in question," they must, in other words, be "integral to the distinctive culture of the aboriginal group," "a defining characteristic of their culture," and must be shown to be "an exercise in modern form of a pre-contact practice, custom or tradition" which has "continuity with [those practices] that existed prior to contact with European society." 47 Such continuity is not necessarily the result of an unbroken

47 This test of cultural distinctiveness is outlined under the heading, "The Aboriginal Right" in $R$. v. Van der Peet, supra note 1 at para. 2-3. 
history that reaches from the near present back to pre-contact societies. An integral, distinct, traditional practice is subject to flux and reflux; it can be left aside and picked up again later, resumed after an interruption. The main thing is that there must be an essential similarity between pre-contact times and the present.

There are important political implications that follow from this approach to culture. If evolutionism leads to a distorted philanthropic impulse to "uplift" and "civilize" the "backward" societies to the point where they can live as happy individuals integrated in the nation, the Court's current emphasis on distinctivism can lead to an equally distorted preservationist impulse to control the pace of change, to "protect" those original people living close to nature, to recognize distinct rights only to the extent that they are far removed from economic and political development.

It is not entirely accurate to say that there can be no significant innovations applied to (or imposed upon) aboriginal practices that do not diminish the continuity between a pre-contact tradition and its present form. The Court does allow unilateral government regulation of fishing, hunting, and gathering activities, but has not viewed this as a significant divergence from a pre-contact tradition, not a compromise of the central significance of a practice or custom and not a form of discontinuity with practices that existed prior to contact with European society. This approach effectively removes from aboriginal control the authority they held in pre-contact times (and in post-contact times, despite a number of ineffectively imposed regimes of government management) to regulate the very activities that are central to aboriginal practice. It is, as far as significant legal events go, a change of fundamental importance which goes to the very heart of that way of life based upon hunting, fishing and gathering, yet it is not discussed as a source of divergence from pre-contact aboriginal cultures.

Canada's courts are sometimes required to deal with a tension between popular ideas that can be characterized as "rigid liberalism"-based upon the idea of equality as a legal absolute-and the protection of aboriginal peoples through regimes of distinct rights. Liberal states, including their judiciaries, have tended to act upon indigenous rights only to the extent that they do not cross over into affirmations of sovereignty, beyond the familiar and comfortable territory of individual rights and the equal dignity of citizens. Without special regimes of rights, however, aboriginal societies have little defense against a process of cultural assimilation that in the past has proven to be more destructive than emancipatory. 


\title{
26 Ronald Niezen
}

\begin{abstract}
Résumé
L'auteur examine la démarche canadienne à l'égard de la reconnaissance des droits des peuples autochtones. La discussion porte surtout sur les problèmes, autant conceptuels que juridiques, au centre du discours culturel de la Cour suprême du Canada. L'approche de la Cour envers la culture, la "spécificité culturelle" et les "droits culturels" ne concorde pas avec les conceptions anthropologiques ou historique contemporaines de la culture. En particulier, cette approche a tendance à "figer dans le temps" les droits culturels autochtones. Les idées culturelles de la Cour sont basées en partie sur les témoignages des experts (y compris des perspectives autochtones), sur les droits de l'homme et sur l'opinion publique, mais ils ont aussi des qualités qui leur sọnt propres. Ces dernières sont orientées vers les questions politiques entourant la souveraineté de la Couronne et les revendications d'autodétermination des peuples autochtones. Le discours culturel de la Cour est inséparable d'une opposition entre une politique libérale d'égalité et les droits et revendications spécifiques des peuples distincts.
\end{abstract}

\begin{abstract}
The author examines the current Canadian approach to the recognition of the rights of Aboriginal peoples. The discussion focuses especially on the conceptual and legal problems at the centre of the Supreme Court's cultural discourse. The Court's approach to culture, "cultural distinctiveness" and "cultural rights" does not concord with current anthropological or historical conceptions of culture. With this approach Aboriginal cultural rights tend to appear "frozen in time". The Court's cultural ideas are based in part on expert testimony (from the perspective of Aboriginal peoples, amongst others), on human rights and on public opinion, but they also have their own inherent logic. They are essentially oriented toward political questions surrounding the sovereignty of the Crown and the claims of indigenous peoples to self-determination. The cultural discourse of the Court is inseparable from the tension between the liberal politics of equality and the specific rights and claims of distinct peoples.
\end{abstract}

Ronald Niezen

Humboldt-Universität zu Berlin

Institut für Europäische Ethnologie

Schiffbauerdamm 19

10117 Berlin Germany

niezen@harbornet.com 